\title{
Apoptosis in Thyroid Diseases: A Histochemical Study
}

\author{
CHIKAKo TANIMOTO, SHUZO HIRAKAWA, HideTAKa KAWASAKI, \\ NOBUHIKO HAYAKAWA, AND ZENSUKE OTA \\ Third Department of Internal Medicine, Okayama Medical School, Okayama 700, Japan
}

\begin{abstract}
Recent studies demonstrate that apoptosis is an important process in physiological and pathological cell death. We examined the apoptotic phenomena in thyroid tissues by two methods: immunohistological and in situ end-labeling of fragmented DNA (ISEL). In thyroid tissues from patients with Hashimoto's thyroiditis and thyroid cancer, fragmented nuclear DNA and Le ${ }^{Y}$ (apoptosis associated antigen) were observed. In tissues from patients with Graves' disease, $\mathrm{Le}^{\mathrm{Y}}$ and bcl-2 oncoprotein were expressed, but no ISEL positive cells were observed. In contrast, thyrocytes in normal thyroid tissues were not stained with ISEL or anti-Le ${ }^{Y}$ antibodies (Abs). Fas antigen (Ag) was expressed in various thyroid tissues, including normal subjects. The clinical meaning of this was not determined. These results suggest that the apoptotic process takes place in Hashimoto's thyroiditis and thyroid cancer, and is overcome in Graves' disease by bcl-2 expression.
\end{abstract}

Key words: Apoptosis, Thyroid, $\mathrm{Le}^{\mathrm{Y}}, \mathrm{Bcl}-2$ protein, Fas antigen

(Endocrine Journal 42: 193-201, 1995)

RECENT studies have demonstrated that apoptosis is an important process in physiological and pathological cell death. A lot of these studies focused mainly on apoptosis in the immune system [1], embryonic development [2], cancer or normal cell turnover, and cancer cell death induced by cytotoxic drugs [3]. Some nervous system diseases were also reported to relate to apoptosis [4]. With regard to the thyroid gland, experimental thyroid involution induced by a moderate iodine diet preceding a low iodine diet was accompanied by apoptosis in mice [5]. The deprivation of growth factor induced apoptosis in cultured dog thyrocytes [6]. Little, however, is known about apoptosis in human thyroid diseases.

The morphological changes in apoptotic cells are cytoplasmic shrinkage and condensed nuclear chromatin. Methodologically, it is difficult to explore apoptosis in situ, because apoptotic cells are abrupt-

Received: September 1, 1994

Accepted: November 25, 1994

Correspondence to: Dr. Chikako TANIMOTO, Third Department of Internal Medicine, Okayama Medical School, 2-5-1 Shikata-cho, Okayama 700, Japan ly phagocytised in vivo, and their histological changes are difficult to detect. In this study we used the ISEL method [7] to detect nuclear DNA fragmentation, which is characteristic of apoptosis, and immunostaining with monoclonal antibody $\mathrm{Ab})$ to $\mathrm{Le}^{\mathrm{Y}}$, which has been reported to be associated with early apoptotic changes [8].

A destructive mechanism in autoimmune thyroiditis has not been established, although some humoral and cellular immunities have been suggested [9-18]. As for cellular immunity, recent studies have indicated that cytotoxic lymphocytes (CTLs) induce apoptosis in target cells (19-21). In Hashimoto's thyroid tissue, infiltrating lymphocytes which have the markers of the $T$ cell have been reported to play an important role in its pathogenesis [11, 13-15].

Monoclonal anti-Fas $\mathrm{Ab}$ has been reported to mediate apoptosis in many cell lines [22, 23]. Although the expression of Fas has been demonstrated in some mouse organs [24], its role has been unclear except in immune systems [25]. In this study we also examined the expression of Fas Ag on thyroid cells by the immunohistological method. 


\section{Materials and Methods}

\section{Tissue preparations}

Thyroid tissues were obtained at the time of thyroidectomy. The diagnosis was based on clinical criteria and confirmed by appropriate laboratory tests and histological findings. None of the patients with thyroid cancer was treated with pre-operative radiotherapy or cytotoxic anti-cancer chemotherapy. Tissues from 9 patients with Hashimoto's thyroiditis, 11 patients with Graves' disease, and 9 patients with thyroid cancers (7 papillary adenocarcinomas, 1 follicular adenocarcinoma, and 1 medullary carcinoma) were examined. As normal control tissues, paranodular thyroid tissue from 9 patients with a thyroid tumors (5 papillary adenocarcinomas, 2 follicular adenocarcinomas and 2 adenomas) and thyroid tissue from 1 patient with a laryngeal carcinoma were used. Tissue samples from 22 patients were fixed in formaldehyde, embedded in paraffin and stored. They were sliced into $3 \mu \mathrm{m}$-thick sections. These sections were deparaffinized in a xylene bath 3 times for 5 min each time. Endogeneous peroxidase was inactivated by a $0.3 \% \mathrm{H}_{2} \mathrm{O}_{2}$-methanol solution for $30 \mathrm{~min}$. The other 17 samples were frozen and sliced into 5-7 $\mu \mathrm{m}$ thick-sections and stored at $-20^{\circ} \mathrm{C}$. Frozen sections were fixed in acetone for immunohistological staining or in methanol for ISEL staining.

\section{Immunohistological analysis}

After deparaffinization, the sections were immunostained with various monoclonal Abs according to conventional procedures. Briefly, the sections were incubated with primary Abs for $30 \mathrm{~min}$ at room temperature (RT) and rinsed in phosphatebuffered saline (PBS). The second anti-mouse immunoglobulin Abs which were labeled with biotin were then added to the slides. After $30 \mathrm{~min}$ incubation at RT, they were washed in PBS. The sections were covered with Peroxidase-avidin solution (Nichirei, Tokyo, Japan), incubated $30 \mathrm{~min}$ at RT, washed in PBS, and stained with diaminobentizine (DAB) $/ \mathrm{H}_{2} \mathrm{O}_{2}$ solution $\left(0.02 \% 3,3^{\prime}-\mathrm{DAB}\right.$ in $50 \mathrm{mM}$ Tris- $\mathrm{HCl}$ buffer, $\mathrm{pH} 7.4$, containing $0.005 \% \mathrm{H}_{2} \mathrm{O}_{2}$ ) for $7-10 \mathrm{~min}$ at RT. The staining was terminated by washing the sections in distilled water (DDW). Frozen sections were immunostained with fluorescence labeled second antibodies. Primary Abs were anti-Le ${ }^{\mathrm{Y}}$ BM1/JIM$\mathrm{RO} \operatorname{IgM} \mathrm{Ab}(50 \times$ diluted; Japan Immunoresearch Laboratory, Takasaki, Japan), anti-Fas IgM Ab (300 $\times$ diluted; Medical Biology Laboratory Inc., Nagoya, Japan), anti-bcl-2 oncoprotein IgG Ab $(20 \times$ diluted; DAKO, Kyoto, Japan). A negative control for non-specific immunoglobulin binding was employed in which the primary Abs were omitted.

Three observers evaluated the preparations independently. When disagreements arose among them, they were discussed and the results were determined. Histological evaluation was on a scale of - to +++ . - was defined as negative staining of a whole slide. \pm was defined as focal and weak staining. + was defined as focal positive (in one or several foci) or diffuse weak staining. ++ was defined as staining between + and +++ . +++ was defined as diffuse strong staining.

\section{In situ end-labeling of fragmented DNA (ISEL)}

Fragmented DNA was detected in situ according to the method of Gavrieli et al. [7] with minor modifications. Briefly, the deparaffinized (as described above) sections were treated with $20 \mu \mathrm{g} /$ $\mathrm{m} l$ proteinase $\mathrm{K}(\mathrm{PK})$ (Boehringer Manheim/Yamanouchi, Tokyo, Japan) for $20 \mathrm{~min}$ at RT, and the slides were washed in DDW. To avoid the nonspecific binding of biotin and avidin, blocking solutions of avidin and biotin (Nichirei, Tokyo, Japan), respectively, were added to the slides. The slides were incubated for $10 \mathrm{~min}$ at RT, then washed in DDW each time. Next, they were immersed in terminal deoxynucleotidyl transferase (TdT) buffer (100 mM sodium cacodylate, $2 \mathrm{mM}$ cobalt chloride, $0.2 \mathrm{mM}$ dithiothreitol $\mathrm{pH}$ 7.2). Next, $0.3 \mathrm{eU} / \mu l$ biotinylated dUTP (Boehringer Manheim/Yamanouchi, Tokyo, Japan) in TdT buffer was added to cover the sections, and the sections were incubated in a humidified atmosphere at 37 ${ }^{\circ} \mathrm{C}$ for $90 \mathrm{~min}$. After incubation the TdT solution was removed, and the reaction was terminated by adding TB buffer ( $30 \mathrm{mM}$ sodium chloride, $3 \mathrm{mM}$ sodium citrate) for $30 \mathrm{~min}$ at RT. The sections were stained with peroxidase-avidin as mentioned under immunostaining. To identify the ISEL-positive cells as thyrocytes, the second staining with a monoclonal $\mathrm{Ab}$ to thyroperoxidase, $2 \mathrm{~F} 4$ (established in our laboratory [26]) was supplemented. This 
time immunostaining was done by the DAB-Co method [27] instead of DAB. Coloring of the former was cloudy blue; the latter was brown. After the usual ISEL staining the slides were preincubated with DAB-Co solution $(50 \mathrm{mg} \mathrm{DAB} \bullet 4 \mathrm{HCl}$ in 100 $\mathrm{ml} 0.05 \mathrm{M}$ Tris- $\mathrm{HCl}$ buffer, $\mathrm{pH} 7.6$ containing 1.5 $\mathrm{ml} 1 \% \mathrm{CoCl}_{2}$ ) for $3 \mathrm{~min}$ at $\mathrm{RT}$, then $10 \mu l \mathrm{H}_{2} \mathrm{O}_{2}$ was added. The sections were stained for $5 \mathrm{~min}$ and washed in DDW. The frozen sections were treated the same as the paraffin sections, except for the following: (a) fixation was done with methanol; (b) the incubation with PK was omitted to avoid detachment of the tissues; (c) FITC-avidin was used instead of Peroxidase-avidin and DAB; (d) the second staining with $2 \mathrm{~F} 4$ was omitted.

As a positive control, some sections were pretreated with DNase I $(0.4 \mathrm{mg} / \mathrm{ml}$; Sigma Chemical Co., St. Louis, Mo) dissolved in DN buffer $(30 \mathrm{mM}$ Tris- $\mathrm{HCl}$ buffer, $\mathrm{pH} 7.2,140 \mathrm{mM}$ sodium cacodylate, $4 \mathrm{mM} \mathrm{MgCl}_{2}$ ) after PK treatment.

Evaluation of ISEL staining was done as follows: Every field of each section was observed micro- scopically at $\times 200$ magnification, and ISEL positive cells were counted. The scoring was performed as follows: - indicates that there were no positive cells on a whole slide, + indicates several positive cells on a whole slide, ++ indicates a few positive cells in several foci, and +++ indicates several positive cells in many foci.

\section{Results}

Tissue sections from a total of 39 patients were stained by the immunohistological and ISEL methods (Table 1).

$\mathrm{Le}^{\mathrm{Y}}$-positive cells were observed in 7 out of 9 Hashimoto's thyroid tissues, 8 out of 11 Graves' disease tissues, all 9 thyroid cancer tissues and none of the normal thyroid tissues. $\mathrm{Le}^{\mathrm{Y}}$-expressing cells shrank and clustered in Hashimoto's tissues (Fig. 1a, b). In Graves' and cancer tissues, they did not shrink and formed complete follicles (Fig 1c, d).

ISEL-positive cells were observed in 8 out of 9

Table 1. Evaluation of tissue samples stained with immunohistological and in situ end labeling of fragmented DNA (ISEL) methods

\begin{tabular}{|c|c|c|c|c|c|c|c|c|c|c|c|}
\hline cases $^{1)}$ & $\mathrm{Le}^{Y 2)}$ & ISEL $^{3)}$ & bcl-2 ${ }^{2)}$ & HLA-DR $^{2)}$ & Fas $^{2)}$ & cases $^{1)}$ & $\mathrm{Le}^{Y 2)}$ & ISEL $^{3)}$ & bcl-2 2$)$ & HLA-DR ${ }^{2)}$ & Fas $^{2)}$ \\
\hline $\mathrm{H}_{1}$ & ++ & ++ & - & ++ & + & $\mathrm{C}_{1}$ & ++ & +++ & ++ & - & +++ \\
\hline $\mathrm{H}_{2}$ & - & ++ & \pm & +++ & + & $\mathrm{C}_{2}$ & ++ & +++ & + & + & \pm \\
\hline $\mathrm{H}_{3}$ & + & + & \pm & ++ & + & $\mathrm{C}_{3}$ & ++ & ++ & ++ & - & +++ \\
\hline $\mathrm{H}_{4}$ & + & + & - & ++ & + & $\mathrm{C}_{4}$ & ++ & - & ++ & - & ++ \\
\hline $\mathrm{H}_{5}$ & ++ & - & - & +++ & + & $\mathrm{C}_{5}$ & + & - & - & + & + \\
\hline $\mathrm{H}_{6}$ & + & + & \pm & ++ & - & $\mathrm{C}_{6}$ & +++ & ++ & - & + & - \\
\hline $\mathrm{H}_{7}$ & + & + & ND & ++ & + & $\mathrm{C}_{7}$ & ++ & ++ & - & - & - \\
\hline $\mathrm{H}_{8}$ & + & + & - & ++ & - & $\mathrm{C}_{8}$ & + & + & - & - & - \\
\hline $\mathrm{H}_{9}$ & - & + & - & ++ & + & $\mathrm{C}_{9}$ & ++ & - & - & - & +++ \\
\hline $\mathrm{G}_{1}$ & ++ & - & ++ & +++ & +++ & $\mathrm{N}_{1}$ & - & - & + & - & ++ \\
\hline $\mathrm{G}_{2}$ & ++ & - & ++ & + & ++ & $\mathrm{N}_{2}$ & - & - & + & ND & + \\
\hline $\mathrm{G}_{3}$ & + & - & ++ & + & +++ & $\mathrm{N}_{3}$ & - & - & + & - & + \\
\hline $\mathrm{G}_{4}$ & + & - & + & \pm & + & $\mathrm{N}_{4}$ & - & - & + & - & - \\
\hline $\mathrm{G}_{5}$ & - & - & ++ & + & + & $\mathrm{N}_{5}$ & - & - & ND & - & + \\
\hline $\mathrm{G}_{6}$ & - & - & ++ & \pm & +++ & $\mathrm{N}_{6}$ & - & - & - & - & + \\
\hline $\mathrm{G}_{7}$ & - & - & - & \pm & + & $\mathrm{N}_{7}$ & - & - & - & - & \pm \\
\hline $\mathrm{G}_{8}$ & ++ & - & + & ++ & +++ & $\mathrm{N}_{8}$ & - & - & - & - & - \\
\hline $\mathrm{G}_{9}$ & + & - & + & \pm & - & $\mathrm{N}_{9}$ & - & - & - & - & - \\
\hline $\mathrm{G}_{10}$ & + & - & \pm & ++ & - & $\mathrm{N}_{10}$ & - & - & - & - & - \\
\hline$G_{11}$ & + & - & - & + & ++ & & & & & & \\
\hline
\end{tabular}

1'Thyroid tissue samples from patients with Hashimoto's thyroiditis (H), Graves' disease (G), thyroid cancer (C), and normal control $(\mathrm{N}) . \mathrm{H}_{1-5}, \mathrm{G}_{1-7}, \mathrm{C}_{1-5}$ and $\mathrm{N}_{1-5}$ are paraffin sections. The others are frozen sections. $\mathrm{C}_{1}$ is histologically medullary carcinoma. $C_{2}$ is follicular adenocarcinoma. $C_{3-9}$ are papillary adenocarcinomas. ${ }^{2)}$ Immunohistological staining with anti-Le ${ }^{\mathrm{Y}} \mathrm{Ab}\left(\mathrm{Le}^{\mathrm{Y}}\right)$, anti-bcl-2 protein $\mathrm{Ab}$ (bcl-2), anti-HLA-DR Ab (HLA-DR), and anti-Fas Ab (Fas). ${ }^{3)}$ Tissue staining by ISEL method (ISEL). Scoring systems for immunohistological stainings and ISEL are defind in "Materials and Methods". ND: not done. 
cases of Hashimoto's thyroiditis, 6 out of 9 cases of thyroid cancer and none of Graves' or normal thyroid cases. ISEL-positive cells, whose nuclei were stained, were isolated and scattered. They often exhibited condensed nuclear chromatin (Fig. 2a-c, e, f). Such cells were rarely (less than 30 foci in one slide) seen, even in +++ ones. In Graves' tissues no ISEL-positive cells were detected (Fig. 2d). In ISEL staining, non-specific staining occurred often in frozen sections. Negative controlled sections without dUTP and/or TdT revealed that it was due to non-specific binding of dUTP to nuclei in the frozen sections. No such non-specific phenomena were observed in the paraffin sections, except in one case $\left(\mathrm{C}_{2}\right)$. Fixation with formaldehyde could not avoid the non-specific staining in frozen sections. So in this study we regarded strongly fluorescing cells as positive. Control
DNase I-treated sections showed intensive staining of all nuclei in the preparations (picture not shown). The distribution of ISEL-positive cells did not accord with that of $\mathrm{Le}^{\mathrm{Y}}$ - positive cells and was usually less extensive.

Bcl-2 protein was expressed weakly in three Hashimoto's tissues and was often observed in small follicles, which seemed to be regenerative (Fig. 3a). In Graves' thyroid relatively strong expression of bcl-2 was observed (Fig. 3b), but not in all cases. Some tissues from patients with thyroid cancers and normal thyroid also expressed bcl-2 (Fig. 3c, d). As for immunostaining with anti-bcl-2 protein $\mathrm{Ab}$, frozen sections tended to express relatively weak and less frequent staining compared with paraffin sections. This difference may be due to the relatively smaller size of frozen sections and lower detectability of the immunofluorescent meth-
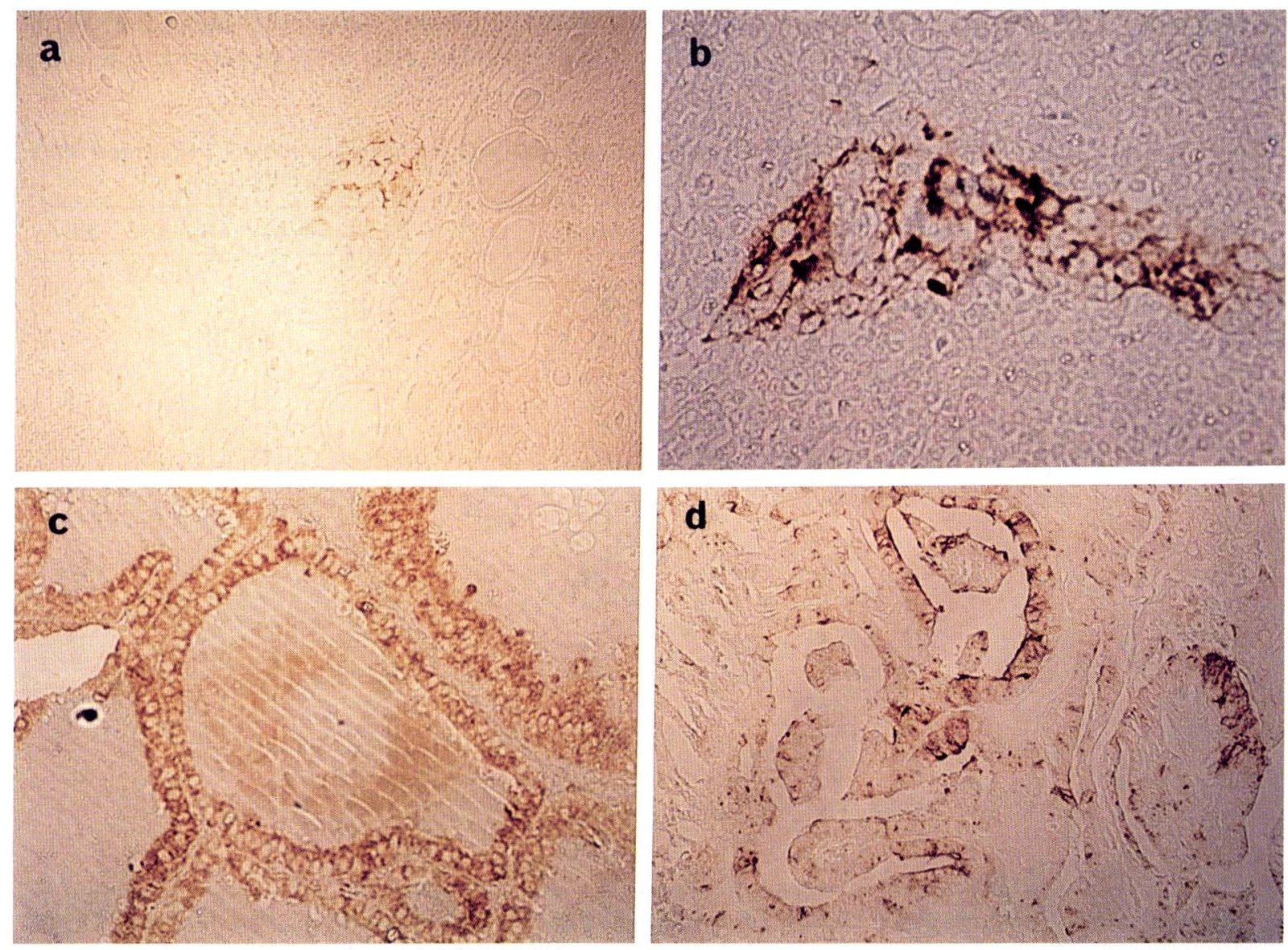

Fig. 1. Thyroid tissue sections stained with anti-Le ${ }^{Y} \mathrm{Ab}$. Positive staining is manifested as a brown cytoplasmic color. Le $^{\gamma}$-positive cells are clustered and shrunk in Hashimoto's tissue (a: case $\mathrm{H}_{1} \times 200, \mathrm{~b}$ : case $\mathrm{H}_{4} \times 400$ ). Le ${ }^{\mathrm{Y}}$-positive cells form follicles and do not shrink in Graves' tissue (c: case $G_{1} \times 200$ ). Le ${ }^{Y}$-positive cells have an uneven cytoplasmic color and do not shrink in cancer tissue (d: case $C_{3} \times 200$ ). 

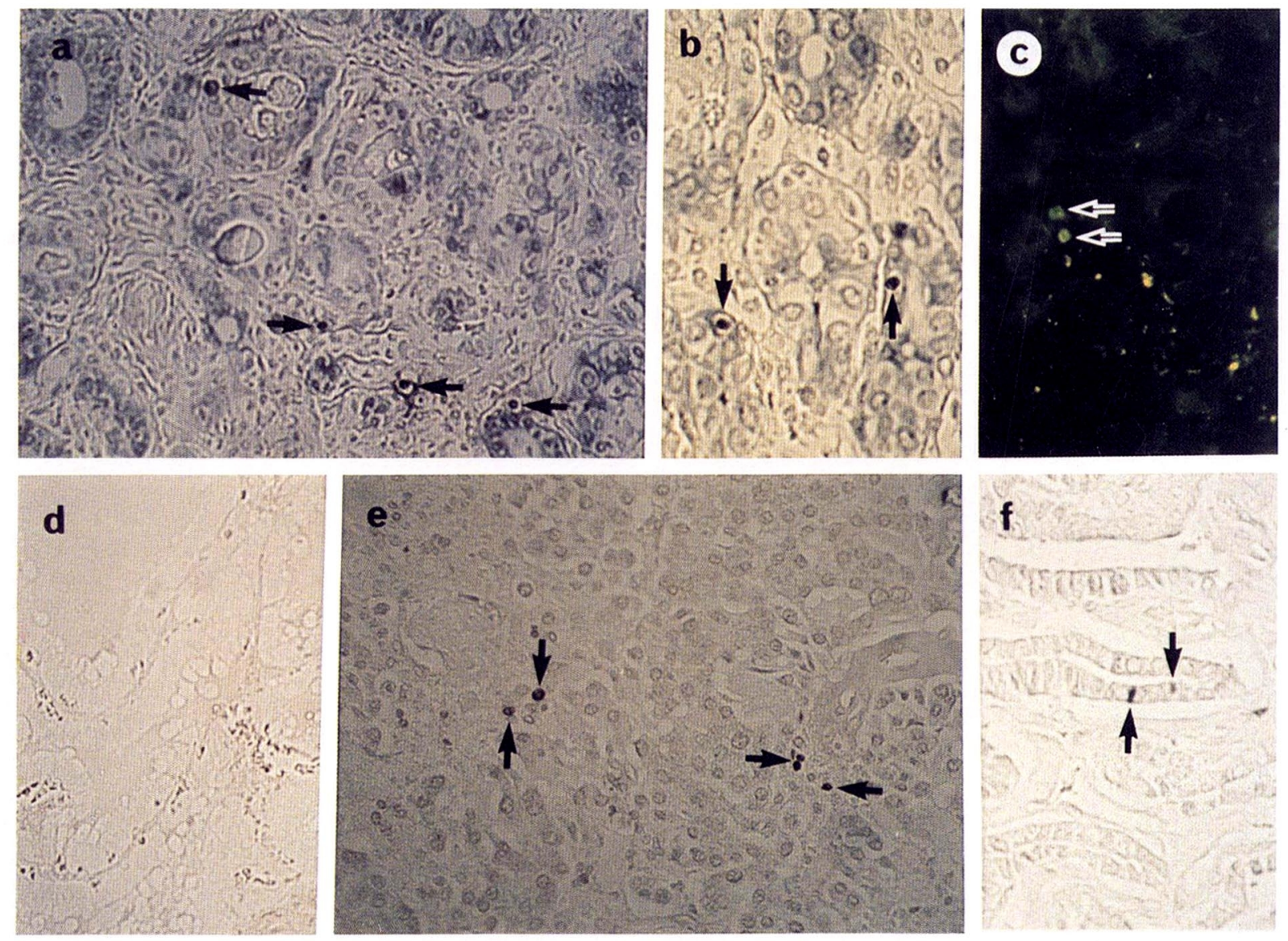

Fig. 2. Thyroid tissue sections stained by the ISEL method. ISEL positive cells, whose nuclei are stained, are scattered (arrows). In Hashimoto's tissue, ISEL-positive cells are also stained with 2F4, anti-thyroperoxidase $\mathrm{Ab}^{\left(a: \mathrm{case}_{1}\right.}$ $\times 200$, b: case $\mathrm{H}_{2} \times 400$ ). This second staining is omitted in the FITC-avidin system (c: case $\mathrm{H}_{9} \times 200$ ). No ISELpositive cells are detected in Graves' tissue (d: case $\left.\mathrm{G}_{4} \times 200\right)$. In this preparation second staining is omitted. In cancer tissue ISEL-positive cells are observed (e: case $C_{1} \times 200$, f: case $C_{2} \times 200$ ). These cells are hardly stained with $2 \mathrm{~F} 4$.

od, but no non-specific staining was observed in negative controlled paraffin sections (Fig. 3e).

HLA-DR Ag was expressed in every section from patients with Hashimoto's thyroiditis and Graves' disease (pictures not shown). Some thyroid cancer tissues also exhibited HLA-DR Ag.

Fas Ag expression was seen in thyroid tissues from patients with various thyroid diseases including normal subjects (Fig. 4a-d). Fas Ag expression did not correlate with the Le ${ }^{\mathrm{Y}}$, ISEL, or bcl-2 protein expression.

\section{Discussion}

In thyroid tissues from 8 out of 9 Hashimoto's thyroiditis patients, nuclear DNA fragmentation, which often involved nuclear shrinkage, was detected by the ISEL method. These results suggest, then, that apoptosis may play a role in cell destruction in Hashimoto's thyroiditis, but no positive ISEL was detected in one case. If the sections were larger, they might have shown ISEL-positive cells, because ISEL-positive cells were rarely seen and were localized even in positive preparations. $\mathrm{Le}^{\mathrm{Y}}$ Ag was also expressed in the Hashimoto's thyroid tissues. This carbohydrate Ag was found immunohistologically to associate with apoptosis in tumorous and normal tissue sections [8]. And it has been reported that $\mathrm{Le}^{\mathrm{Y}}$ positivity has a close correlation with ISEL positivity except in the late necrotic stage, when $\mathrm{Le}^{\mathrm{Y}}$ is negative in spite of positive ISEL staining. In our study, the distribution of ISEL-positive cells was different from that of 

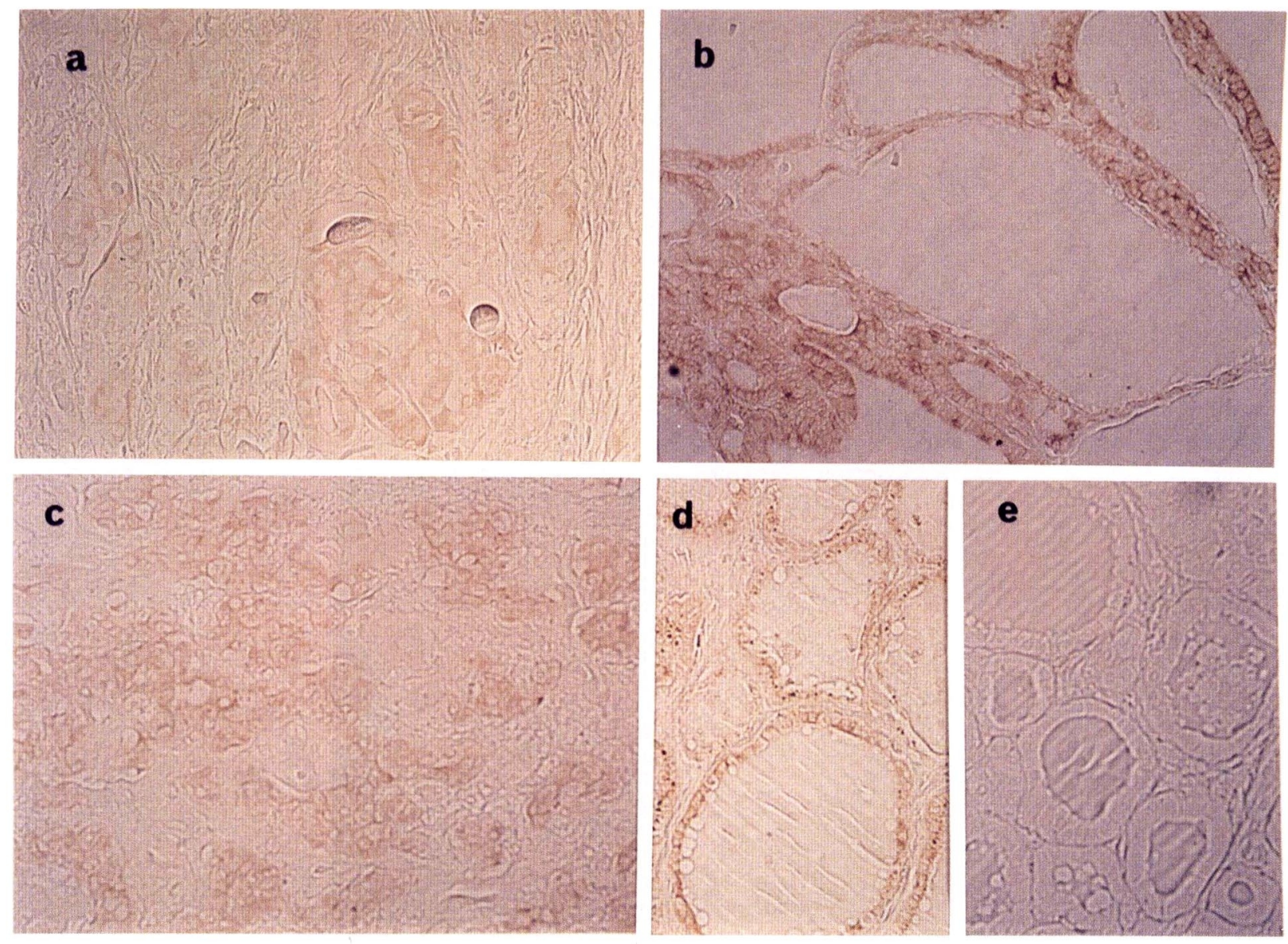

Fig. 3. Thyroid tissue sections stained with anti-bcl-2 protein Ab. Positive staining for bcl-2 protein is expressed as fine brown cytoplasmic staining. Hashimoto's tissue shows faint staining (a: case $\mathrm{H}_{2} \times 200$ ). Graves' tissue shows diffuse staining (b: case $G_{5} \times 200$ ). Cancer cells also express bcl-2 (c: case $C_{1} \times 200$ ). Bcl-2 is expressed in normal thyroid (d: case $N_{1} \times 200$ ). No non-specific staining is observed in negative controlled paraffin sections (e: case $G_{2}$ $\times 200)$.

Le $^{\mathrm{Y}}$-positive cells. Compared to the latter, the former were scattered and rare. This discrepancy may be due to the differences between the two distinct phenomena i.e. DNA fragmentation and expression of $\mathrm{Le}^{\mathrm{Y}} \mathrm{Ag}$ in the apoptotic process. As another explanation, $\mathrm{Le}^{\mathrm{Y}}$ may be expressed not only in the apoptotic process. In our study, two distinct staining forms were observed in $\mathrm{Le}^{\mathrm{Y}}$-positive cells. One was that $\mathrm{Le}^{\mathrm{Y}}$-positive cells shrank and were always scattered or clustered. These appearances tended to be observed in Hashimoto's tissues. The other was that $\mathrm{Le}^{\mathrm{Y}}$-positive cells did not shrink and formed complete follicles. These types of cells tended to appear in Graves' disease or thyroid cancer tissues. And some correlation was observed between $\mathrm{Le}^{\mathrm{Y}}$ and HLA-DR expression in Graves' tissues. These data suggest that the $\mathrm{Le}^{\mathrm{Y}}$ expres- sion of the former type may correspond to apoptosis and that of latter type to some inflammatory process or rapid cell turnover.

In Graves' disease tissues, no fragmented nuclear DNA was detected, in spite of abundant $\mathrm{Le}^{\mathrm{Y}}$ expression. This discrepancy between ISEL staining and $\mathrm{Le}^{\mathrm{Y}}$ expression may be for the reasons discussed above. Graves' disease is characterized by its symptoms of hyperthyroidism induced by stimulatory TSH receptor Abs or thyroid stimulating antibodies (TSAbs). It therefore seems reasonable that tissue destruction or fragmented DNA was hardly seen in Graves' thyroid. And some resistant mechanism, which is represented in bcl-2 expression for example, should be expected. Bcl-2 was reported by many investigators as a proto-oncogene, whose product inhibits apoptosis 

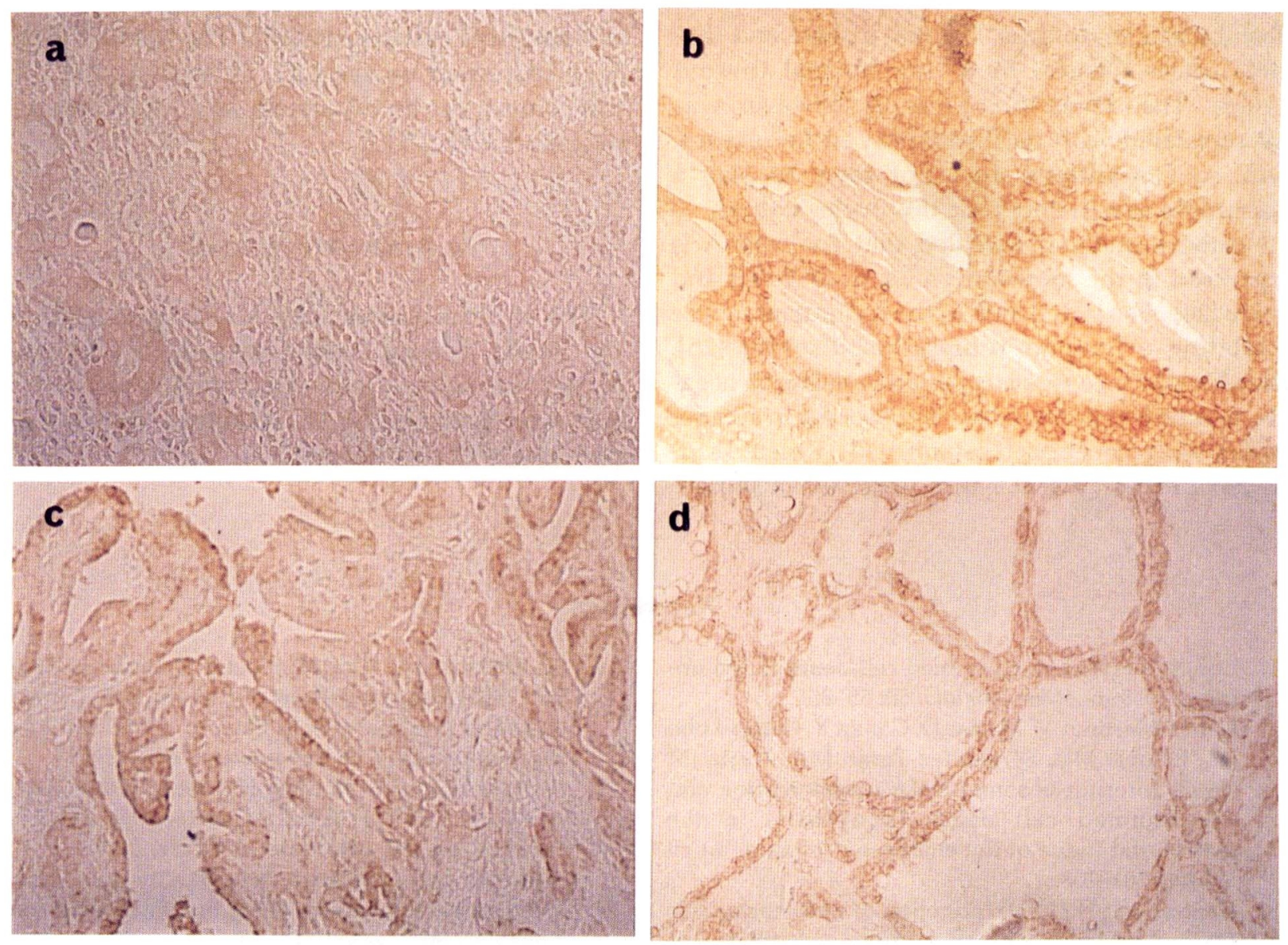

Fig. 4. Thyroid tissue sections stained with anti-Fas Ab. Fas positive cells show brown cytoplasmic staining. Fas Ag is expressed weakly in Hashimoto's tissue (a: case $\mathrm{H}_{2} \times 200$ ), strongly in Graves' tissue (b: case $\mathrm{G}_{1} \times 200$ ), in thyroid cancer (c: case $C_{3} \times 200$ ), and also in normal thyroid tissue (d: case $\mathrm{N}_{1} \times 200$ ).

in certain hemato-poietic [28, 29] or non-haematopoietic cell lines [30-32]. It is also reported to be expressed in some normal adult tissues, including the thyroid gland [33]. In our study most of the Graves' tissues expressed bcl-2 protein, and some of normal and cancer tissues also did, but some of Hashimoto's tissues expressed bcl-2 protein weakly. In Graves' disease, the frequency and intensity of bcl-2 expression leads us to suspect that a rescue system from apoptosis is at work. Such a rescue system is assumed to depend on TSAb. It is interesting that TSAb paradoxically increases mRNA of c-myc and c-fos oncogenes [34, 35], which has been reported to play a substantial role in apoptosis [36, 37].

Then what induces such destruction in autoimmune thyroiditis? There are several hypotheses: 1) cytolysis caused by antibodies and complements $[9,10], 2)$ ADCC by killer (K) cells [11, 12], 3) cyto- toxicity by natural killer (NK) cells or CTLs [11, 13-15], and 4) cytokines produced by $\mathrm{T}$ cells or other infiltrating cells [16-18]. Hypotheses 2) and 3) are suspected in this case, because it has been reported that CTLs, NK cells and K cells cause DNA fragmentation in their target cells [19-21]. This accords with what was observed in this study. To confirm this, further examinations in vitro are needed.

In thyroid cancer sections, $\mathrm{Le}^{\mathrm{Y}}$ was expressed in all cases. And in 6 out of 9 cases, DNA fragmentation was observed in spite of bcl-2 expression. These data suggest that apoptosis takes part in cancer cell death. We cannot determine whether apoptosis is induced by cytotoxic cells or is a natural course in rapidly growing cancer cells. Bcl-2 in cancer cells is thought to be related to some carcinogeneses.

Fas was expressed in thyroid epithelial cells of 
Hashimoto's thyroiditis, Graves' disease and thyroid cancer tissues, including normal thyroid tissues. The expression of Fas Ag, however, was not correlated with ISEL positivity or Le ${ }^{\mathrm{Y}}$ expression, so Fas antigen does not seem to play a discernible role in apoptotic thyrocytes in vivo.

Northern analysis revealed that Fas mRNA is expressed in the mouse thymus, liver, heart and ovary [24]. Fas is deficient in the lpr mutant mouse exhibiting a lymphoproliferation disorder [25]. Therefore its role was suggested to relate to negative selection of thymocytes. But its roles in another tissues have never been established. Recent studies have revealed that Fas is involved in some $\mathrm{T}$ cell-mediated cytotoxicity [38]. The Fas-ligand has been identified on the CTL hybridoma [39]. In this context, Fas on thyrocytes seems to play a role in contact with CTLs.

\section{Acknowledgments}

The thyroid tissues were kindly presented by Dr. Sumizi Sasaki, a chief surgeon of Okayama National Hospital. Some paraffin sections of thyroid were prepared by Dr. Kazunari Murakami, a pathologist of that hospital.

\section{References}

1. Cohen JJ (1991) Programmed cell death in the immune system. Adov immunol 50: 55-85.

2. Garcia-Martinez V, Macias D, Gañan Y, Garcia-Lobo JM, Francia MV, Fernandez-Teran MA, Hurle JM (1993) Internucleosomal DNA fragmentation and programmed cell death (apoptosis) in the interdigital tissue of the embryonic leg bud. J Cell Sci 106: 201-208.

3. Kaufmann SH (1989) Induction of endonucleolytic DNA cleavage in human acute myelogenous leukemia cells by etoposide, camptothecin, and other cytotoxic anticancer drugs: a cautionary note. Cancer Res 49: 5870-5878.

4. Deryk TL, Agata C, Christian JP, Edward RW, Andrea JW, Carl WC (1993) Apoptosis is induced by $\beta$-amyloid in cultured central nervous system neurons. Proc Nati Acad Sci USA 90: 7951-7955.

5. Mahmoud I, Colin I, Many M-C, Denef J-F (1986) Direct toxic effect of iodine in excess on iodinedeficient thyroid glands: epithelial necrosis and inflammation associated with lipofuscin accumulation. Exper Molecul pathol 44: 259-271.

6. Dremier S, Golstein J, Mosselmans R, Dumont JE, Galand P, Robaye B (1994) Apoptosis in dog thyroid cells. Biochem Biophy Res Commun: 52-58.

7. Gavrieli Y, Sherman Y, Ben-Sasson SA (1992) Identification of programmed cell death in situ via specific labeling of nuclear DNA fragmentation. J Cell Biol 119: 493-501.

8. Hiraishi K, Suzuki K, Hakomori S, Adachi M (1993) $\mathrm{Le}^{\mathrm{Y}}$ antigen expression is correlated with apoptosis (programmed cell death). Glycobiology 3: 381-390.

9. Forbes IJ, Roitt IM, Doniach D, Solomon IL (1962) The thyroid cytotoxic autoantibodies. J Clin Inv 41: 996-1006.

10. McLachian SM, Pegg CAS, Atherton MC, Middleton
SL, Dickinson A, Clark F, Proctor SJ, Proud G, Smith BR (1986) Subpopulations of thyroid autoantibody secreting lymphocytes in Graves' and Hashimoto thyroid glands. Clin Exp Immunol 65: 319-328.

11. Iwatani Y, Amino N, Mori H, Matsuzuka F, Kuma K, Miyai K (1982) A microcytotoxicity assay for thyroid-specific cytotoxic antibody, antibody-dependent cell-mediated cytotoxicity and direct lymphocyte cytotoxicity using human thyroid cells. J Immunol methods 48: 241-250.

12. Bogner U, Scheusener H, Wall JR (1984) Antibodydependent cell mediated cytotoxicity against human thyroid cells in Hashimoto's thyroiditis but not Graves' disease. J Clin Endocrinol Metab 59: 734738.

13. Del Prete GF, Maggi E, Mariotti S, Tiri A, Vercelli D, Parronchi P, Macchia D, Pinchera A, Ricci M, Romagnani S (1986) Cytolytic T lymphocytes with natural killer activity in thyroid infiltrate of patients with Hashimoto's thyroiditis: analysis at clonal level. J Clin Endocrinol Metab 62: 52-57.

14. Akasu F, Morita T, Resetkova E, Miller N, Asaku R, Jamieson C, Volpe R (1993) Reconstitution of severe combined immunodeficient mice with intrathyroidal lymphocytes of thyroid xenografts from patients with Hashimoto's thyroiditis. J Clin Endocrinol Metab 76: 223-230.

15. Iwatani $Y$, Hidaka $Y$, Matsuzuka F, Kuma K, Amino $\mathrm{N}$ (1993) Intrathyroidal lymphocytes subsets, including unusual $\mathrm{CD}^{+}{ }^{+} \mathrm{CD} 8^{+}$cells and $\mathrm{CD} 3^{\text {lo }} \mathrm{TCR}$

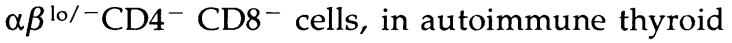
disease. Clin Exp Immunol 93: 430-436.

16. Del Prete GF, Tiri A, Mariotti S, Pinchera A, Ricci M, Romagnani S (1987) Enhanced production of $\gamma$ interferon by thyroid-derived $\mathrm{T}$ cell clones from patients with Hashimoto's thyroiditis. Clin Exp 
Immunol 69: 323-331.

17. Del Prete GF, Tiri A, De Carli M, Mariotti S, Pinchera A, Chreten I, Romagnani S, Ricci M (1989) High potential to tumor necrosis factor $\alpha$ (TNF- $\alpha$ ) production of thyroid infiltrating $\mathrm{T}$ lymphocytes in Hashimoto's thyroiditis: A peculiar feature of destructive thyroid autoimmunity. Autoimmunity 4: 267-276.

18. Nagataki S, Eguchi K (1992) Cytokines and immune regulation in thyroid autoimmunity. Autoimmunity 13: 27-34.

19. Sellins KS, Cohen JJ (1991) Cytotoxic T lymphocytes induce difference type of DNA damage in target cells of different origins. J Immunol 147: 795803.

20. Ucker DS (1987) Cytotoxic T lymphocytes and glucocorticoids activate an endogenous suicide process in target cells. Nature 327: 62-64.

21. Duke RC, Cohen JJ, Chervenak R (1986) Difference in target cell DNA fragmentation induced by mouse cytotoxic T lymphocytes and natural killer cells. J Immunol 137: 1442-1447.

22. Yonehara S, Ishii A, Yonehara M (1989) A cell-killing monoclonal antibody (anti-Fas) to a cell surface antigen co-down regulated with the receptor of tumor necrosis factor. J Exp Med 169: 1747-1756.

23. Ito $\mathrm{N}$, Yonehara $\mathrm{S}$, Ishii $\mathrm{A}$, Yonehara M, Mizushima S, Sameshima M, Hase A, Seto Y, Nagata S (1991) The polypeptide encoded by the cDNA for human cell surface antigen Fas can mediate apoptosis. Cell 66: 233-243.

24. Fukunaga $\mathrm{WR}$, Brannan $\mathrm{Cl}$, Ito $\mathrm{N}$, Yonehara $\mathrm{S}$, Copeland NG, Jenkins NA, Nagata S (1992) The cDNA structure, expression and chromosomal assignment of the mouse Fas antigen. J Immunol 148: 1274-1279.

25. Watanabe-Fukunaga $\mathrm{R}$, Brannan $\mathrm{Cl}$, Copeland NG, Jenkins NA, Nagata S (1992) Lymphoproliferation disorder in mice explained by defects in Fas antigen that mediates apoptosis. Nature 356: 314-317.

26. Hirakawa S, Shimizu I, Sunada M, Suzuki S, Ota Z (1986) Production of monoclonal antibodies to thyroid microsome antigens. Frontiers Thyroidol 2: 1415-1419.

27. Hsu SM, Soban E (1982) Color modification of diaminobentizine (DAB) precipitation by metallic irons and its application for double immunohistochemistry. J Histochem Cytochem 30: 1079-1082.

28. Vaux DL, Cory S, Adams JM (1988) Bcl-2 gene pro- motes haemopoietic cell survival and cooperates with c-myc to immortalize pre-B cells. Nature 335: $440-442$.

29. Hockenbery D, Nuñez G, Milliman C, Schreiber RD, Korsmeyer SJ (1990) Bcl-2 is an inner mitochondrial membrane protein that blocks programmed cell death. Nature 348: 334-336.

30. Mah Sp, Zhong LT, Liu Y, Robhani A, Edwatds $\mathrm{RH}$, Bredesen DE (1993) The protooncogene bcl-2 inhibits apoptosis in PC12 cells. J Neurochem 60: 1183-1186.

31. Ohmori T, Podack ER, Nishino K, Takahashi M, Miyahara Y, Takeda Y, Kubota N, Funayama Y, Ogasawara H, Ohira T, Ohta T, Saijo N (1993) Apoptosis of lung cancer cells caused by some anticancer agents (MMC, CPT-11, ADM) is inhibited by bcl-2. Biochem Biophys Res Commun 192: 30-36.

32. Allsopp TE, Wyatt S, Paterson HF, Davies AM (1993) The protooncogene bcl-2 can selectively rescue neurotrophic factor-dependent neurons from apoptosis. Cell 73: 295-307.

33. Lu QL, Poulsom R, Wong L, Hanby AM (1993) Bcl2 expression in adult and embryonic nonhaematopoietic tissues. J Pathol 169: 431-437.

34. Hatabu $H$, Kasagi $K$, Iida $Y$, Nosaka T, Misaki T, Hidaka A, Tokuda Y, Endo K, Mori T, Lee K, Tsuboi K, Hatanaka M, Konishi J (1991) Induction of c-fos and c-myc mRNA expression by immunoglobulin $G$ from patients with Graves' disease in thyrotropin-dependent rat thyroid cell line (FRTL5). Clin Endocrinol 34: 349-356.

35. Huber GK, Safirstein R, Neufeld D, Davies TF (1991) Thyrotropin receptor autoantibodies induce human thyroid cell growth and c-fos activation. J Clin Endocrinol Metab 72: 1142-1147.

36. Evan GI, Wyllie AH, Gilbert CS, Littlewood TD, Land H, Brooks M, Waters CM, Penn LZ, Hancook DC (1992) Induction of apoptosis in fibroblasts by c-myc protein. Cell 69: 119-128.

37. Smeyne RJ, Vendrell M, Hayward M, Baker SJ, Miao GG, Schilling K, Robertson LM, Curran T, Morgan JI (1993) Continuous c-fos expression precedes programmed cell death in vivo. Nature 363: 166-169.

38. Rouvier E, Luciani MF, Golstein P (1993) Fas involvement in $\mathrm{Ca}^{2+}$ independent $\mathrm{T}$ cell-mediated cytotoxicity. J Exp Med 177: 195-200.

39. Suda T Nagata S (1994) Purification and characterization of the Fas-ligand that induces apoptosis. $J$ Exp Med 179: 873-879. 